\title{
PENGARUH PERILAKU WPS DALAM PENCARIAN PENGOBATAN PMS, LINGKUNGAN DAN STATUS KESEHATAN TERHADAP KUALITAS HIDUP WPS DI KELURAHAN DADAP TANGERANG TAHUN 2011
}

\author{
Siti Rafika Putri \\ Dosen AKBID Al-Ikhlas Cisarua Bogor \\ Jl. hankam Desa Jogjogan Cisarua Bogor \\ Email:sitirafikaputri@yahoo.co.id
}

\begin{abstract}
ABSTRAK
Penyakit menular seksual merupakan masalah kesehatan masyarakat didunia termasuk di Indonesia. WPS ditengarai sebagai menyebarkan penyakit menular seksual akibat perilaku sex bebas. Dari penderita PMS tersebut banyak yang tidak melakukan pengobatan difasilitas kesehatan sehingga menurunkan kualitas hidup dan status kesehatan penderita. Tujuan penelitian ini adaalah Mengetahui pengaruh perilaku WPS dalam pencarian pengobatan PMS, Lingkungan, status kesehatan terhadap kualitas hidup WPS di Kelurahan Dadap Tangerang tahun 2011. Penelitian ini menggunakan desain cross sectional, data primer. Sampel sebanyak 108 orang. Variabel yang diteliti perilaku WPS dalam pencarian pengobatan, lingkungan, status kesehatan, kualitas hidup, faktor enabling, faktor predispocing,faktor reinforcing. Pengolahan data menggunakan SmartPLS (Partical Least Square). Hasil dari analisis adalah Kualitas hidup WPS dipengaruhi langsung oleh status kesehatan dan lingkungan, dan dipengaruhi tidak langsung oleh faktor reinforcing di Kelurahan Dadap Tangerang Tahun 2011. Oleh karena itu, jika ada penelitian selanjutnya dengan tema yang sama, maka perlu dikembangkan variabel, indikator, dan teori baru dari yang didapat.

Kata Kunci : Perilaku, kualitas hidup, status kesehatan
\end{abstract}

\section{ABSTRACT}

Sexually transmitted diseases are a public health problem in the world, including in Indonesia. WPS is suspected as the spread of sexually transmitted diseases caused by free sex behavior. PMS is a lot of people who do not perform the treatment at health facilities resulting in lower quality of life and health status of patients. Knowing the purpose of this study is WPS influence behavior in the search for treatment of PMS, environment, health status on quality of life in the Village Dadap Tangerang WPS in 2011. This study uses cross-sectional design, primary data. Sample of 108 people. WPS variables studied in the search for treatment of behavioral, environmental, health status, quality of life, enabling factors, predispocing factors, reinforcing factors. Data processing using SmartPLS (partical least squares). The results of the analysis is the quality of life is directly affected by the WPS and the environmental health status, and indirectly influenced by the reinforcing factor in the Village of Tangerang Dadap in 2011. Therefore, if there is further research with a similar theme, it is necessary to develop the variables, indicators, and new theories gained.

Keyword: Behavior, Quality Life, Health

\section{PENDAHULUAN}

Penyakit menular seksual (PMS) merupakan suatu kelompok penyakit yang penularannya terutama melalui hubungan seksual yang biasanya menyerang alat kelamin. ${ }^{1}$ Pada dasarnya besar masalah PMS di Indonesia sulit diketahui karena keterbatasan data. Hal ini dikarenakan sekitar $30-50 \%$ penderita PMS tidak berobat, dan sekitar $50-70 \%$ dari yang mencari pengobatan tidak berobat ke sarana kesehatan. Disamping itu sekitar 70\% wanita dan $30 \%$ pria yang terinfeksi klamidia, serta $80 \%$ wanita dan $20 \%$ pria yang terinfeksi gonorea tidak menunjukan gejala. $^{2}$ Hasil survey data Puslitkes Universitas Indonesia mencatat tahun 2003 di Indonesia terdapat 190 ribu hingga 270 ribu pekerja seks komersial dengan 7 hingga 10 juta pelanggan. Sedangkan Depkes 
mencatat tahun 2007 yaitu 7,4\% PSK mengidap penyakit sipilis dan 5,7 \% mengidap kencing nanah. Hasil dari Serological test for syphilis yang dilakukan tahun 2006 pada wanita penjaja seks di Indonesia di laporkan bahwa dari 66.664 WPS yang diperiksa $4.097(6,15 \%)$ positif sifilis. $^{3}$

Pasien yang menderita PMS (Penyakit menular seksual) dapat mengalami gangguan kesehatan reproduksi tersebut sehingga terjadi penurunan kualitas hidup. ${ }^{4}$ Kualitas hidup menjadi isu yang penting dalam pelayanan kesehatan karena jatuh sakit, baik kronis maupun terminal, dapat menurunkan kualitas hidup seseorang. Kualitas hidup juga menjadi pertimbangan penting dalam upaya pencegahan penyakit menular seksual dan memperbaiki status kesehatan setelah terjadinya pennyakit menular seksual terhadap kehidupan pasien. ${ }^{5}$

Dalam kerangka konsep faktor reinforcing merupakan variabel eksogen, sedangkan variabel endogen adalah faktor predisposisi, faktor enabling, perilaku WPS dalam pencarian pengobatan PMS, lingkungan WPS, status kesehatan, kualitas hidup.,

Hasil yang didapatkan akan berguna untuk mengetahui kualitas hidup WPS, status kesehatan WPS, Lingkungan, serta perilaku pencarian WPS dalam pencarian pengobatan sehingga dapat dijadikan evaluasi bagi WPS maupun tenaga kesehatan professional terhadap pelayanan kesehatan wanita penjaja seks. Hal ini akan membantu mengurangi resistensi obat, meningkatkan kesembuhan sehingga biaya pengobatan yang dperlukan menjadi lebih murah serta mencegah komplikasi yang timbul. $^{7}$

\section{METODE}

Penelitian ini menggunakan cross sectional. Pengambilan data dilaksanakan pada bulan April tsampai Januari 2012 di Kelurahan Dadadp Tangerang. Populasi penelitian ini adalah seluruh WPS di Kelurahan Dadap yang berjumlah 108 WPS, dengan criteria dapat menjawab sendiri kuesioner dan memenuhi kriteria bahwa responden dapat berkomunikasi dengaan baik dalam memberikan informasi yang dibutuhkan.

Besar sample yaitu total sampling yaitu seluruh WPS di Kelurahan Dadap yang berjumlah 108 WPS. Instrumen yang digunakan berupa daftar pertanyaan (kuesioner) yang mengukur ke-7 variabel yaitu variabel kualitas hidup, status kesehatan, perilaku pencarian pengobatan PMS, lingkungan, faktor Predisposisi, faktor Reinforcing, faktor Enabling.

Kuesioner menggunakan sistem skoring berdasarkan pengukuran skala sematik diferensial dengan penilaian skala nilai 1-5. Nilai 1 merupakan nilai terendah dan nilai ke 5 adalah nilai tertinggi dari suatu penilaian atau presepsi pada suatu pertanyaan. Jumlah pertanyaan pada setiap pertanyaan adalah 9 butir pertanyaan jadi jumlah total pertanyaan adalah 63 pertanyaan.

Ketujuh variabel memiliki 3 indikator. Variabel kualitas hidup terdiri atas indikator kesahjeteraan fisik, kesahjeteraan psikologis, kepuasaan pendapatan. Variabel status kesehatan terdiri dari indikator program kesehatan, pemeriksaan kesehatan secara berkala, pemeliharaan situasi sehat. Variabel perilaku WPS dalam pencarian pengobatan PMS terdiri dari indikator pengetahuan kesehatan, sikap terhadap kesehatan, praktek kesehatan. Variabel lingkungan terdiri dari indikator keadaan lingkungan, kebersihan individu, kebersihan lingkungan. Variabel faktor predisposisi terdiri dari indikator kepercayaan responden, pendidikan, sosial ekonomi. Variabel faktor Enabling terdiri dari indikator fasilitas kesehatan, sarana prasarana, ketersediaan petugas kesehatan. Variabel faktor Reinforcing terdiri dari indikator perilaku petugas kesehatan, dukungan rekan atau keluarga, ketertarikan responden dalam mencari informasi kesehatan.

Variasi jawaban semua daftar pertanyaan pada instrument diujikan terhadap 6 karakteristik responden tersebut untuk 
mengetahui apakah variasi jawaban responden terjadi sebagai akibat karakteristiknya. Pengujian dilakukan dengan menggunakan uji $\mathrm{T}$ independent dengan program SPSS. Bila nilai uji $T$ independent memiliki nilai $\mathrm{p}>0.05$ maka pertanyaan atau pernyataan pada instrument tersebut tidak dipengaruhi variasi karakteristik responden.

$$
\text { Data selanjutnya dianalisis }
$$

menggunakan pendekatan Structual Equation Model (SEM) dengan menggunakan Software Smart-PLS menghasilkan measurement model (Outer Model) lengkap dengan nilai Confimatory factor Analysis (CFA) dan goodness of fit (GOF). Nilai CFA diukur dengan melihat hasil olahan Smart-PLS pada nilai lamda (loading factor). Nilai lamda harus lebih besar dari 0,5 pada pengujian outer loading untuk mengatakan nilai factor tersebut merupakan refleksi dari variabelnya. Bila nilai lamda kurang dari 0,5 maka harus diuji ulang setelah dilakukan modifikasi indikator pada variabel tersebut. Outer loading test (loading factor) dilengkapi dengan penilaian pada analysis discriminaty validity yaitu menilai indicator reflektif suatu variabel dengan melihat nilai cross loading antara nilai indicator pada variabel indikator miliknya dan nilai indicator bukan miliknya atau cukup membaca nilai average variance extractor (AVE). nilai AVE tersebut harus berada sama atau lebih besar dari 0,5. Selanjutnya bila nilai semua measurement model sudah fit, dilanjutkan penilaian untuk mengukur besaran reliabilitas masingmasing lamda dengan melihat nilai composite reability. Nilai harus sama dengan atau lebih besar dari 0,7 bila nilai kurang dari 0,7 indikator dianjurkan untuk tidak dimasukan ke dalam model, khususnya untuk model eksploratori. Composite reability perlu diperkuat dengan nilai alpha Cronbach dari masing-masing variabel untuk mengetahui tingkat kekuatan refleksi indikator terhadap variabelnya. Hubungan yang kuat harus memiliki nilai lebih besar dari 0,6. Semua perhitungan tersebut dapat dilihat pada hasil PLS.
Nilai structural model yaitu besarnya nilai hubungan antar variabel yang dibangun oleh model dan telah memiliki nilai goodness of fit yang cukup. Nilai tersebut dapat dilihat pada perhitungan BT atau bosstraping dengan melihat nilai original sample yang merupakan nilai path tersebut signifikan yaitu nilai T-statistik. Nilai path tersebut signifikan bila nilai $\mathrm{T}$ lebih besar dari 1,96 yaitu dengan tingkat kesalahan $5 \%$.

Langkah selanjutnya adalah membangun persamaan untuk model dan menghitung nilai $\mathrm{Q}^{2}$ atau goodness of fit dari model yang dibangun, yaitu menilai besaran variasi data penelitian terhadap fenomena yang dikaji dengan menghitung $\mathrm{R}^{2}$ pada masing-masing variabel terlebih dahulu.

\section{HASIL}

Karakteristik semua variabel endogen (independent atau dependent) dan eksogen (independen) yang diteliti memiliki distribusi data yang normal dan homogen. Penyebaran karakteristik responden digambarkan pada tabel 1 .

Tabel 1 Karakteristik Demografi responden

\begin{tabular}{lcc}
\hline Variabel & $\mathrm{n}$ & $\%$ \\
\hline Umur & & \\
$\quad \leq 20$ tahun & 23 & 21,3 \\
$\quad$ 21 tahun & 85 & 78,7 \\
Pendidikan terakhir & & \\
$\quad \leq$ SD & 63 & 58,4 \\
$\quad \leq$ SLTA & 45 & 41,6 \\
Status Pernikahan & & \\
$\quad$ Pernah menikah & 77 & 71,3 \\
$\quad$ Tidak pernah & 31 & 28,7 \\
Status mempunyai anak & & \\
$\quad$ Belum punya anak & 60 & 55,6 \\
$\quad$ Sudah punya anak & 48 & 44,4 \\
Lama menjadi WPS & & \\
$\quad<2$ tahun & 57 & 52,8 \\
$\quad>2$ tahun & 51 & 37,2 \\
Umur pertama & & \\
berhubungan seksual & & \\
$\quad<20$ tahun & 87 & 80,6 \\
$\quad>20$ tahun & 21 & 19,4 \\
\hline
\end{tabular}


Selanjutnya dilakukan pengujian antara sebaran karakteristik responden dengan jawaban yang diberikan responden secara bivariat dengan uji chi-square. Hasilnya menunjukan tidak didapatkan variasi semua hasil uji chi square pada setiap variabel memiliki nilai $\mathrm{p}>0,05$.

Hasil pengujian outer model pada tiap indicator menghasilkan CFA dengan nilai alfa 0,54-0,97 dan nilai $\mathrm{T}$ 1,5-23,3. GOF measurement model memberikan hasil seperti tabel 2.

Tabel 2. Nilai GOF outer model jawaban akibat variasi karakteristik karena

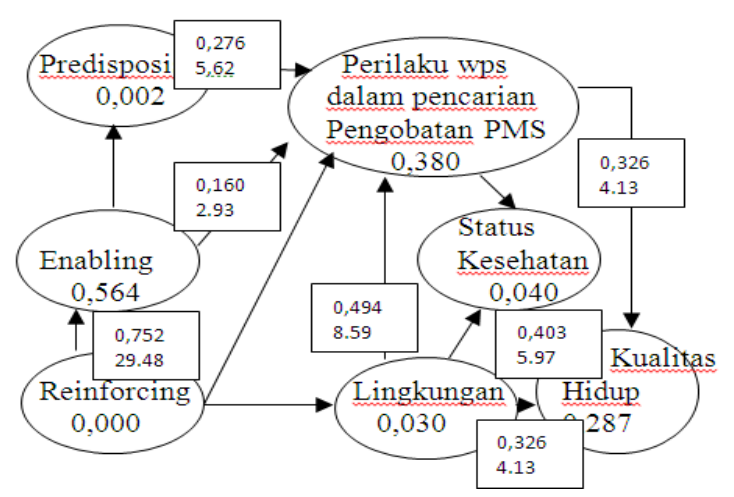

Gambar 1 Structual Model (dengan path/rho dan nilai $\mathrm{T}$ dalam kurung)

\section{PEMBAHASAN}

Hubungan Karakteristik WPS dengan

\begin{tabular}{|c|c|c|c|c|}
\hline Variabel & AVE & $\begin{array}{l}\text { Composite } \\
\text { Reability }\end{array}$ & $\begin{array}{l}\text { Cronbachs } \\
\text { Alnha }\end{array}$ & ${ }_{\text {Square }}^{\mathrm{R}}$ \\
\hline Enabling & 0.699 & 0.821 & 0.589 & 0.564 \\
\hline Kualihid & 0,502 & 0.743 & 0.502 & 0.287 \\
\hline Lingkungan & 0 & 0 & 0 & 0.030 \\
\hline Predisposisi & i 0,679 & 0.861 & 0.810 & 0.002 \\
\hline Perilaku & 0,663 & 0.797 & 0.491 & 0.380 \\
\hline Reinforcing & 1,000 & 1,000 & 1,000 & 0 \\
\hline Status Kesh & 0,568 & 0.796 & 0.634 & 0.040 \\
\hline
\end{tabular}

kualitas hidup, status kesehatan, perilaku pencarian pengobatan PMS, lingkungan kesehatan, predisposisi, enabling, reinforcing.

Berdasarkan hasil penelitian didapatkan gambaran karakteristik WPS Kelurahan Dadap Tangerang tahun 2011 berdasarkan karakteristik umur WPS didapatkan Umur WPS $\leq 20$ tahun (18.5\%), $\geq 21$ tahun $(81.5 \%)$,

Pada tabel 2 variabel lingkungan tidak Berdasarkan karakteristik pendidikan terdapat AVE, Composite reability, cronbachs alphepakhir WPS adalah $\leq$ SD (61.1\%) dan dikarenakan variabel lingkungan termasuk indikat@MA (38.9\%), berdasarkan data penelitian formatif. Pada variabel reinforcing tidak terdapat $R_{\text {pat }}$ disimpulkan bahwa WPS yang square dikarenakan variabel eksogen. Unøerpendidikan SMA / SMP lebih percaya variabel lainnya menunjukan nilai GOF Outer modelli dalam menjalani pekerjaan mereka memiliki lamda $>0,5$ untuk semua indicator kecusalibagai Wanita pekerja seks terlihat dari lingkungan, dengan nilai $\mathrm{T}$ yang signifikan $(>1,96$ ) ra mereka berdandan atau cara WPS Nilai reabilitas dan validitas juga tinggi (lebih besallam melayani pelanggan, dibandingkan dari yang diisyaratkan) sehingga proses pembacanPS yang lulus/ belum tamat SD, WPS dapat dilanjutkan untuk GOF inner modelnyahg ada dikelurahan Dadap tidak ada yang (Gambar 1). berpendidikan hingga perguruan tinggi ataupun yang berstatus mahasiswa.

Berdasarkan karakteristik status pernikahan WPS didapatkan bahwa WPS yang pernah atau dalam status menikah terdapat 77 orang $(71.3 \%)$ dan yang belum menikah 31 orang $(28.7 \%)$, pada WPS yang berada dikelurahan Dadap tangerang, status pernikahan tidak dijadikan masalah dalam bekerja, meskipun mereka masih bersuami, WPS masih tetap diperbolehkan untuk tetap melayani para tamu. 
Berdasarkan karakteristik WPS dari jumlah anak yang dimiliki, WPS yang belum mempunyai anak ada 60 orang $(55.6 \%)$ dan yang sudah mempunyai anak ada 48 orang $(44.4 \%)$, berdasarkan hal ini penulis menilai bahwa berkaitan dengan perkawinan gdan perceraian di usia muda, keinginan masyarakat untuk pasangan baru cepat mempunyai anak, tidak heran pula bahwa sebagian WPS sudah menjadi Ibu. Jumlah anak mereka berkisar satu sampai tiga orang anak tapi mayoritas.

Berdasarkan karakteristik lama menjadi WPS <2tahun sebanyak 57 orang $(52.7 \%)$ dan pada WPS $>2$ tahun sebanyak 51 orang $(47.3 \%)$ sedangkan karakteristik berdasarkan WPS umur pada saat pertama kali hubungan seksual didapatkan $<20$ tahun sebanyak 87 orang $(80.6 \%)$ dan $>20$ tahun sebanyak 21 orang (19.4\%), adapun alasanalasan yang dikemukakan WPS tentang pertama kali berhubungan seksual terjadi karena diperkosa, melakukan suka dengan suka dengan pacarannya, maupun hubungan seksual pertama kali terjadi saat menjadi WPS di kelurahan dadap.

Peneliti juga melakukan uji $\mathrm{T}$ pada hasil penelitian untuk mengetahui apakah ada hubungan atau pengaruh antara karakteristik WPS dengan jawaban setiap variabel. Berdasarkan hasil Uji didapatkan bahwa tidak ada satupun yang berhubungan antara karakteristik WPS yang meliputi umur WPS, Pendidikan terakhir, status pernikahan, mempunyai anak, lama menjadi WPS, umur pertama kali pada saat berhubungan seksual dengan variabel jawaban kualitas hidup, status kesehatan, lingkungan kesehatan, perilaku pencarian pengobatan PMS, faktor predisposisi, enabling, reinforcing.

\section{Pengaruh predisposisi, enabling, reinforcing, perilaku pencarian pengobatan PMS, lingkungan kesehatan, status kesehatan terhadap kualitas hidup \\ Menurut model yang dikembangkan oleh Green dalam notoadmodjo (2003) ndiatas menjelaskan bahwa kualitas hidup dipengaruhi oleh status kesehatan dimana}

status kesehatan ini dapat dilihat dari perilaku atau gaya hidup serta lingkungan dimana individu itu berada. menerangkan bahwa perilaku kesehatan dipengaruhi oleh 3 faktor utama, yaitu : (1) faktor predisposisi (2) faktor enabling (3) faktor reinforcing. Tujuan dari penelitian ini adalah ingin melihat Pengaruh predisposisi, enabling, reinforcing, perilaku pencarian pengobatan PMS, lingkungan kesehatan, status kesehatan terhadap kualitas hidup.

\section{Pengaruh Status kesehatan terhadap kualitas hidup}

Berdasarkan hasil penelitian didapatkan bahwa Model pengaruh status kesehatan terhadap kualitas hidup memberikan nilai R-Square sebesar 0.28745 yang dapat diinterprestasikan bahwa variabilitas konstruk kualitas hidup yang dapat dijelaskan oleh konstruk variabel lain yang diteliti sebesar $28.7 \%$ sedangkan $71.3 \%$ dijelaskan oleh variabel lain diluar yang diteliti. Dan berdasarkan koefisien parameter 0.403942 yang berarti terdapat pengaruh positif antara status kesehatan dengan kualitas hidup. Semakin tinggi status kesehatan maka semakin tinggi kualitas hidup dengan nilai T-statistic 5.972204 atau t-statistic $\geq 1.96$.

Kualitas hidup WPS sangat berkaitan dengan status kesehatan. Status kesehatan WPS yang rendah maka kualitas hidup juga rendah. Kualitas hidup merupakan resultan dari status kesehatan fisik, mental, kognitif serta lingkungan. Bukti dari sejumlah penyakit yang diderita oleh WPS menunjukan bahwa kualitas hidup terkait kesehatan dapat berdampak pada kelangsungan hidup.

Penelitian ini juga telah membuktikan adanya hubungan antara status kesehatan dengan kualitas hidup WPS. WHO dan ILO mengemukakan bahwa kesehatan fisik dan psikologis dapat sangat berkaitan dengan kualitas hidup yang akan berdampak pada peningkatan kapasitas/produktivitas mereka. Oleh karena itu sangat penting memelihara kesehatannya dan tentunya juga harus didukung oleh 
lingkungan kesehatan. Hal ini sesuai dengan hasil penelitian peneliti bahwa ada pengaruh antara status kesehatan dengan kualitas hidup.

Hubungan antara factor reinforcing terhadap perilaku WPS dalam pencarian pengobatan PMS

Berdasarkan hasil penelitian didapatkan bahwa model hubungan reinforcing mempunyai Direct effect dengan perilaku WPS dalam pencarian pengobatan PMS yaitu 0.05777179 (5.7\%).

\section{Pengaruh reinforcing terhadap lingkungan kesehatan}

Berdasarkan hasil penelitian didapatkan Model reinforcing terhadap lingkungan WPS memberikan nilai 0.03022 yang dapat diinterprestasikan bahwa variabilitas konstruk lingkungan kesehatan yang dapat dijelaskan oleh variabilitas konstruk lain yang diteliti sebesar 3.02\% sedangkan $96.98 \%$ dijelaskan oleh variabel lain yang tidak diteliti. Dan berdasarkan koefisien parameter -0.176966 yang berarti terdapat hubungan negative reinforcing terhadap lingkungan WPS. Semakin tinggi reinforcing semakin rendah lingkungan kesehatan dengan nilai statistik sebesar 3.112123 (t tabel signifikasi 1.96) oleh karena nilai t-statistik lebih besar dari nilai t tabel 1.96.

Pengaruh reinforcing terhadap enabling

Pada penelitian ini peneliti mempunyai tiga indikator pada variabel enabling yaitu (1) fasilitas kesehatan (2) sarama prasarana (3) ketersediaan petugas kesehatan sedangkan pada variabel reinforcing adapun memiliki indikator sebagai berikut :(1) perilaku petugas kesehatan (2) dukungan rekan/keluarga (3) ketertarikan responden dalam mencari pengobatan kesehatan.

Didapatkan hasil penelitian yaitu Model pengaruh reinforcing terhadap enabling memberikan nilai R-Square sebesar 0.56462 yang dapat diinterprestasikan bahwa variabilitas konstruk enabling yang dapat dijelaskan oleh variabel lain yang diteliti sebesar $56.5 \%$ sedangkan $44.5 \%$ dijelaskan oleh variabel yang tidak diteliti. Berdasarkan koefisien parameter didapatkan nilai0.752394 yang berarti terdapat pengaruh positif reinforcing terhadap enabling. Semakin tinggi reinforcing maka semakin tinggi enabling dengan nilai tstatistik sebesar 29.48639 signifikan (t tabel signifikan 5\%=1.96 oleh karena nilai $\mathrm{T}$ statistik lebih besar dari t tabel 1.96.

\section{Pengaruh perilaku pencarian pengobatan PMS terhadap status kesehatan}

Pada penelitian ini peneliti mempunyai tiga indikator pada variabel perilaku WPS dalam pencarian pengobatan PMS yaitu (1) pengetahuan kesehatan responden (2) sikap WPS terhadap kesehatan (3) praktek kesehatan. Adapun indikator yang diberikan peneliti kepada responden mengenai status kesehatan meliputi (1) pemeliharaan situasi sehat (2) pemeriksaan kesehatan yang dilakkukan secara berkala oleh petugas kesehatan (3) program kesehatan yang dibuat oleh tenaga kesehatan untuk meningkatkan status kesehatan.

Berdasarkan hasil penelitian didapatkan nilai t-statistic antara variabel perilaku WPS dalam pencarian pengobatan PMS terhadap status kesehatan adalah 1.244833 maka nilai t lebih kecil dari t tabel yaitu $5 \%$ atau nilai $\mathrm{t}<1.96$ maka didapatkan tidak ada hubungan antara perilaku WPS dalam pencarian pengobatan PMS dengan status kesehatan.

\section{Pengaruh perilaku pencarian pengobatan PMS terhadap kualitas hidup}

Pada penelitian ini peneliti mempunyai tiga indikator pada variabel perilaku WPS dalam pencarian pengobatan PMS yaitu (1) pengetahuan kesehatan responden (2) sikap WPS terhadap kesehatan (3) praktek kesehatan. Adapun indikator yang diberikan peneliti kepada responden mengenai kualitas hidup adalah meliputi (1) kesahjeteraan fisik 
kesahjeteraan psikologis (3) kepuasaan pendapatan.

Berdasarkan hasil penelitian didapatkan nilai $\mathrm{t}$-statistic antara variabel perilaku WPS dalam pencarian pengobatan PMS terhadap kualitas hidup adalah 0.328069 maka nilai t lebih kecil dari t tabel yaitu 5\% atau nilai $\mathrm{t}<1.96$ maka didapatkan tidak ada hubungan antara perilaku WPS dalam pencarian pengobatan PMS dengan kualitas hidup.

\section{Pengaruh predisposisi terhadap perilaku pencarian pengobatan PMS}

Pada penelitian ini peneliti mempunyai tiga indikator pada variabel perilaku WPS dalam pencarian pengobatan PMS yaitu (1) pengetahuan kesehatan responden (2) sikap WPS terhadap kesehatan (3) praktek kesehatan. Adapun indikator yang diberikan peneliti kepada responden mengenai predisposisi adalah (1) kepercayaan responden (2) tingkat pendidikan (3) Tingkat sosial ekonomi.

Berdasarkan hasil penelitian didapatkan model pengaruh predisposisi terhadap perilaku WPS dalam pencarian pengobatan PMS memberikan nilai Rsquare sebesar 0.38049 yang dapat diinterprestasikan bahwa variabilitas konstruk perilaku WPS dalam pencarian pengobatan PMS yang dapat dijelaskan oleh variabel lain yang diteliti sebesar $38.04 \%$ sedangkan $61.96 \%$ dijelaskan oleh variabel lain yang tidak diteliti. Berdasarkan koefisiensi parameter didapatkan nilai 0.276625 yang berarti terdapat pengaruh positif predisposisi terhadap perilaku WPS dalam pencarian pengobatan PMS dengan nilai t-statistik sebesar 5.621226 signifikan (nilai $\mathrm{t}$ tabel signifikan $5 \%=1.96$ ) oleh karena nilai $t$ statistic lebih besar dari t tabel 1.96.

\section{Pengaruh antara lingkungan terhadap status kesehatan}

Pada penelitian ini peneliti ingin mengetahui pengaruh antara lingkungan terhadap status kesehatan. Adapun indikator dari variabel lingkungan kesehatan yang diteliti pada penelitian ini adalah (1) keadaan lingkungan (2) kebersihan perorangan (3) kebersihan lingkungan. Sedangkan indikator dari variabel status kesehatan adalah (1) program kesehatan (2) pemeriksaan kesehatan secara berkala (3) pemeliharaan situasi sehat.

Berdasarkan hasil penelitian didapatkan nilai t-statistic antara variabel lingkungan terhadap status kesehatan adalah 1.012092 maka nilai t lebih kecil dari t tabel yaitu $5 \%$ atau nilai $\mathrm{t}<1.96$ maka didapatkan tidak ada hubungan antara lingkungan dengan status kesehatan.

\section{Pengaruh lingkungan terhadap perilaku pencarian pengobatan PMS}

Pada penelitian ini peneliti ingin mengetahui pengaruh antara lingkungan terhadap perilaku WPS dalam pencarian pengobatan PMS. Adapun indikator dari variabel lingkungan kesehatan yang diteliti pada penelitian ini adalah (1) keadaan lingkungan (2) kebersihan perorangan (3) kebersihan lingkungan. Dan tiga indikator pada variabel perilaku WPS dalam pencarian pengobatan PMS yaitu (1) pengetahuan kesehatan responden (2) sikap WPS terhadap kesehatan (3) praktek kesehatan.

Berdasarkan hasil penelitian model pengaruh lingkungan terhadap perilaku WPS dalam pencarian pengobatan PMS memberilan nilai 0.38049 yang dapat diinterprestasikan bahwa variabilitas konstruk perilaku WPS dalam pencarian pengobatan PMS dijelaskan oleh variabel lain yang diteliti sebesar $38.04 \%$ sedangkan $61.96 \%$ dijelaskan oleh variabel lain diluar yang diteliti.besarnya koefisien parameter 0.494052 yang berarti terdapat pengaruh positif lingkungan terhadap perilaku WPS dalam pencarian pengobatan PMS. Semakin tinggi lingkungan maka semakin tinggi perilaku WPS dalam pencarian pengobatan PMS dengan nilai t-statistik 8.596724 oleh karena nilai t-statistik lebih besar dari nilai $\mathrm{t}$ tabel 1.96 . 


\section{Pengaruh lingkungan terhadap kualitas hidup}

Pada penelitian ini peneliti ingin mengetahui pengaruh antara lingkungan terhadap kualitas hidup. Adapun indikator dari variabel lingkungan kesehatan yang diteliti pada penelitian ini adalah (1) keadaan lingkungan (2) kebersihan perorangan (3) kebersihan lingkungan. Dan tiga indikator pada variabel kualitas hidup adalah (1) kesahjeteraan fisik (2) kesahjeteraan psikologis (3) kepuasaan pendapatan.

Berdasarkan hasil penelitian model pengaruh lingkungan terhadap kualitas hidup memberikan nilai $\mathrm{R}$-square sebesar 0.28745 yang dapat diinterprestasikan bahwa variabilitas konstruk kualitas hidup yang dapat dijelaskan oleh variabel lain yang diteliti sebesar $28.7 \%$ sedangkan $71.3 \%$ dijelaskan oleh variabel lain diluar yang diteliti. Berdasarkan koefisiens parameter 0.326457 yang berarti terdapat pengaruh positif lingkungan terhadap kualitas hidup. Semakin tinggi lingkungan kesehatan maka semakin tinggi kualitas hidup dengan nilai t-statistik 4.138345 oleh karena nilai t statistic lebih dari 1.96 .

\section{Pengaruh enabling terhadap perilaku pencarian pengobatan PMS}

Pada penelitian ini peneliti mempunyai tiga indikator pada variabel perilaku WPS dalam pencarian pengobatan PMS yaitu (1) pengetahuan kesehatan responden (2) sikap WPS terhadap kesehatan (3) praktek kesehatan. Adapun indikator yang diberikan peneliti kepada responden mengenai enabling adalah (1) fasilitas kesehatan (2)sarana prasarana (3) ketersediaan petugas kesehatan.

Berdasarkan hasil penelitian didapatkan model pengaruh perilaku pencarian pengobatan terhadap enabling memberikan nilai R-square sebesar 0.56462 yang dapat diinterprestasikan bahwa variabilitas konstruk yang dapat dijelaskan oleh variabel lain yang diteliti $56.5 \%$ sedangkan $53.5 \%$ dijelaskan oleh variabel lain diluar yang diteliti. Berdasarkan koefisien parameter 0.160839 yang berarti terdapat pengaruh positif enabling terhadap perilaku WPS dalam pencarian pengobatan PMS. Semakin tinggi enabling maka semakin tinggi perilaku WPS dalam pencarian pengobatan PMS dengan nilai $t$ statistic 2.924932 oleh karena nilai t statistic lebih besar dari 1.96 .

\section{Pengaruh enabling terhadap predisposisi}

Pada penelitian ini peneliti mempunyai tiga indikator pada variabel enabling adalah (1) fasilitas kesehatan (2)sarana prasarana (3) ketersediaan petugas kesehatan. Adapun indikator yang diberikan peneliti kepada responden mengenai predisposisi adalah (1) kepercayaan responden (2) tingkat pendidikan (3) Tingkat sosial ekonomi.

Berdasarkan hasil penelitian didapatkan nilai t-statistic antara variabel enabling terhadap predispoisi adalah 0.212184 maka nilai $\mathrm{t}$ lebih kecil dari $\mathrm{t}$ tabel yaitu $5 \%$ atau nilai $\mathrm{t}<1.96$ maka didapatkan tidak ada hubungan antara enabling terhadap predispoisi.

\section{KESIMPULAN}

Kualitas hidup WPS dipengaruhi langsung oleh status kesehatan dan lingkungan, dan dipengaruhi tidak langsung oleh faktor reinforcing di Kelurahan Dadap Tangerang Tahun 2011.

\section{DAFTAR PUSTAKA}

[1] Anwar,A. 2000. Pengantar pendidikan kesehatan.Jakarta.2000 : PT.Sastra Hudaya

[2] Augutinus, 2010. Ilmu Penyakit Kulit dan Kelamin. $5^{\text {th }}$ ed. Jakarta: Balai Penerbitan FKUI.

[3] Behrman, A.J. \& Shoff, W.H., 2009. Gonorrhea, University of Pennsylvania. Available from: 
http://emedicine.medscape.com/artic le/782913-overview [accessed 13 April 2010].

[4] Somelus. 2008. Centers for Disease Control and Prevention, 2007. CDC Fact Sheet Genital Herpes. Available from : http://www.cdc.gov/std/healthcomm /factsheets .htm. [accessed 13 April 2010].

[5] WHO.2009. Centers for Disease Control and Prevention, 2009. Sexually Transmitted Disease Surveillance 2008. Georgia: U.S. Department of Health and Human Services, Division of STD Prevention.

[6] Daili, S.F., 2007. Tinjauan Penyakit Menular Seksual (PMS). EGC.Jakarta

[7] Daili, S.F., 2009. Gonore. In: Daili, S.F., et al., Infeksi Menular Seksual. $4^{\text {th }}$ ed. Jakarta: Balai Penerbitan FKUI, 65-76.

[8] Departemen Kesehatan Republik Indonesia, 2009. Manual Pemberantasan Penyakit Menular. Direktorat Jenderal Pengendalian Penyakit dan Penyehatan Lingkungan.

[9] Dwi Lestari. 2010. Pengaruh Pendidikan Kesehatan Terhadap Pengetahuan, Sikap Dan Perilaku Psk Dalam Rangka Pencegahan Ims Di Lokalisasi Gajah Kumpul Kabupaten Pati. Thesis. UGM

[10] Faridah 2010. Presepsi Wanita Penjaja Seks Tentang HIV/AIDS Terhadap Perilakunya Dalam Penggunaan Kondom Seks
Komersial di Kabupaten Bekasi Tahun 2011. Thesis.STIKIM

[11]Febrila harmaini. 2006. Uji keandalan dan kesahihan formulir European Quality of life5dimensions (EQ-DS5) untuk mengukur kualitas hidup terkait pada kesehatan usia lanjut di RSUPNCM.thesis.UI

[12] Ghadishah, D., 2009. Condiloma Acuminata, FACEP. Available from: http://emedicine.medscape.com/artic le/781735-overview [accessed 13 April 2010].

[13] Ghozali, Imam. 2008. Structural Equation Modeling: Metode Alternatif dengan Partial Least Square (PLS) Edisi 2. Semarang: Universitas Diponegoro.

[15]Hakim, L., 2009. Epidemiologi Infeksi Menular Seksual. In: Daili, S.F., et al., Infeksi Menular Seksual. $4^{\text {th }}$ ed. Jakarta: Balai Penerbitan FKUI, 3-16.

[16] Hutapea, N.O., 2009. Sifilis. In: Daili, S.F., et al., Infeksi Menular Seksual. $4^{\text {th }}$ ed. Jakarta: Balai Penerbitan FKUI, 84-102.

[17] Jazan, S., et al. 2003. Prevalensi Infeksi Saluran Reproduksi pada Wanita Penjaja Seks di Bitung,Indonesia. Jakarta: Direktorat Jenderal PPM \& PPL.

[18] Kastner M., et al., 2006. AgeSpecific Search Strategies for Medline, University of Toronto, Faculty of Medicine. Available from: http://www.jmir.org. [Accesed 15 April 2010]. 
[19] Liu, P.F. \& Euerle, B., 2009. Syphilis, Virginia Hospital Center Arlington. Available from: http://emedicine.medscape.com/artic le/229461-overview [accessed 15 April 2010].

[20] Dit Promkes.2009. Panduan Strategi Promosi Kesehatan di Indonesia. Jakarta : Direktorat Promosi Kesehatan, Depkes

[21] Ditjen Kesmas. 2009. Pedoman pencegahan dan penanganan terhadap kekerasan perempuan.Jakarta: Direktorat Promosi kesehatan, Depkes

[22] Depkes RI. 1997. Buku Pegangan Pendidikan Kelompok Sebaya dalam penanggulangan HIV/AIDS dan PMS lainnya di kalangan resiko tinggi. Depkes RI Jakarta.

[23] Depkes RI.2008. Statistik Kasus HIV/AIDS di Indonesia. Ditjen PPM \& PLP Depkes RI. Jakarta

[24] Hastono, S.P. 2001. Modul Analisa Data.Depok :FKM-UI

[25] Nandipinta. 2000. Faktor-faktor yang berhubungan dengan perilaku pencegahan dan pengobatan pada pria /klien yang menderita penyakit menular seksual yang berkunjung ke lokalisasi/tempat prostitusi dikabupaten indramayu tahun 2000.Thesis.UI.Jakarta

[26] Notoadmojo,S. dkk. 2004. Pengantar Pendidikan Kesehatan Masyarakat. Jakarta. FKM-UI.

[27] Notoadmodjo,S. 2005. Pengantar Pendidikan Kesehatan dan Ilmu
Perilaku Kesehatan. Yogyakarta : Penerbit Andi Offiset

[28] Notoadmojo,S. 2010. Promosi Kesehatan dan Ilmu Perilaku. Rineka Cipta.Jakarta

[29] Riono,P. 1999. Gambaran Singkat Gejala Penyakit Menular Seksual. Center for Health Research university of Indonesia, Jakarta.

[30] Sabri, L. \& Hastono,S.1999. Modul Biostatistik \& Statistik Kesehatan. Jurusan Kependudukan \& Biostatistik, FKMUI.Depok

[31] Utomo,dkk.2006. Seks Bebas Tidak Lagi Tabu Bagi Remaja. Kepustakaan Populer Gramedia. Jakarta

[32] Endang R.2010. PerempuanPerempuan Keramat Tunggak. Kepustakaan Populer Gramedia. Jakarta

[33] Taylor.2002. Faktor-faktor yang berhubungan dengan Pekerja Seks Komersial. Thesis.UI

[34] Sarafindo 2002. Kontraindikasi Dalam Kesehatan Reproduksi. Jakarta. Pustaka Sinar Harapan

[35] WHO.2001. Regional Office for Western Pacific. Controlling STI and HIV in Cambodia: The Success of Condom Promotion. Manila: World Health Organization, 2001.

[36] Handayani.2006. Remaja dan Kesehatan Reproduksi. Jawa Timur. Stain Ponorogo 
[37] Kristanto 2010. Studi Kasus Perilaku Wanita Pekerja Seksual Tidak Langsung Dalam Pencegahan Ims, Hiv Dan Aids Di Pub\&Karaoke, Café, Dan Diskotek Di Kota Semarang. Tesis.Universitas Diponegoro

[38] Soejoeti. 2005. Situasi HIV/AIDS di Jawa Tengah tahun 2005. Dinas Kesehatan Kota. Makalah Seminar, Semarang, April 2005.

[39] Khadijah. 2004. Mitos-Mitos Seputar Penyakit Menular Seksual.diakses dari Http://www.bkkbn.go.id.hqweb/ceri a/pengelolaceria/pp3pms. [diunduh 15 September 2011]

[40] Mardjan 2006. Dinamika Kognisi Sosial Pada Pelacur Terhadap Penyakit Menular Seksual. Tesis. Universitas.Muhamadiyah Surakarta.

[41] Masturoh.2011. Hubungan Antara Tingkat Konsumsi Serta Statuskesehatan Terhadap Status Gizi Santri Putri Dipondok Pesantren Modern Kabupaten Bogor. Di Akses dari http://www.scribd.com/doc/7527976 4/13/Status-Kesehatan/ [diunduh 21 Oktober 2011]

[42] Manuaba, Ida Bagus Gde. 1999. Memahami Kesehatan Reproduksi Wanita. Penerbit Arcan. Jakarta.

[43] Hamzah. 2009. Fasilitas jamban keluarga dan pengelolaan limbah di tamalate tahun 2009. Diakses dari http://www.artikelkedokteran.com/5 16/fasilitas-jamban-keluarga-danpengelolaan-air-limbah-dikelurahan-barombong-kecamatan- tamalate-tahun-2009.html [diunduh 14 Desember 2011]

[44] Hambuako. 2009. Dampak Pencemaran Lingkungan Terhadap Kesehatan. Diakses dari http://dinkesbanggai.wordpress.com/ 2009/01/13/dampak-pencemaranlingkungan-terhadap-kesehatan/ [diunduh 14 Desember 2011]

[45] Yobad. 2010. Kasus Pekerjaan Sebagai Penjaja Seks di Kecamatan Rantau Utara Kabupaten Labuhan Batu. Diakses dari http://www.scribd.com/doc/1899033 0/LAPORAN-RISET-PSK [diunduh dari 13 Sepetember 2011] 